\title{
HYPERPYREXIA ASSOCIATED WITH SUCCINYLCHOLINE-INDUCED MUSCLE RIGIDITY: A CASE REPORT
}

\author{
W. H. Thut, M.D., and Harold T. Davenport, M.B., F.F.A.R.C.s."
}

A 5\%-YEAR-OLD BOY was admitted to the Montreal Children's Hospital for elective adeno-tonsillectomy on November 15, 1965. His parents were healthy, as were three older children. The patient had weighed $2.04 \mathrm{~kg}$. at birth and had been admitted to hospital at $2 \frac{1}{2}$ weeks for staphylococcal septicemia, and again at 6 months for bronchopneumonia. His subsequent development had been slow-he had sat at 1 th years, walked at 2 years, and had delayed tooth eruption. At 2\% years he had suffered a slight head injury leading to headaches. He had received aspirin and antibiotics without drug reaction. He was first seen at the Montreal Children's Hospital at age 5 for squint, for which glasses were prescribed. A little later he was seen for nervousness, enuresis, and retarded growth. His condition was then categorized as "failure-to-thrive," and chronic maxillary sinusitis was shown by roentgenogram. He was also said to have trouble with nasal breathing, snoring at night, and recurrent sore throats, and as he had enlarged, infected tonsils and adenoids, he was booked for operation. On admission he weighed $15.5 \mathrm{~kg}$. His chest roentgenogram was normal; haemoglobin was $12.5 \mathrm{gm}$. per cent. He was said to bleed or bruise easily but a haemogram gave normal results (platelets 474,000 , bleeding time 30 sec., clotting time 9 min., prothrombin time 13 sec., haematocrit 41 , M.C.H.C. $35 \%$ ).

Preoperatively he was given $40 \mathrm{mg}$. of pentobarbital at 9.00 A.M. and morphine $1.5 \mathrm{mg}$. with hyoscine $0.15 \mathrm{mg}$. at 10.00 A.M. His temperature was $98^{\circ} \mathrm{F}$., pulse 92 , and respiration 22 at 6.00 A.M. He had slept well and appeared normal. At 11.10 A.M. anaesthesia was induced with nitrous oxide, oxygen, and halothane in a partial rebreathing system. The induction was smooth and uneventful until he was given $15 \mathrm{mg}$. of succinylcholine chloride (Scoline) for intubation. Then, as the patient became apnoeic, the muscles of all limbs became involved in a severe tonic spasm. There was some opisthotonos, the abdominal muscles were rigid, and the jaws were tightly closed. However, artificial ventilation with a mask was easy. The heart rate remained unaltered at 120 per minute, and within three minutes spontaneous ventilation resumed. Methoxyflurane was introduced to the anaesthetic and a second dose of succinylcholine $15 \mathrm{mg}$. was given. Again there was increased stiffness of skeletal muscles, and with much difficulty an endotracheal tube was inserted, the larynx being quite patent. The anaesthetic was continued with nitrous oxide, oxygen, and methoxyflurane with a non-rebreathing circuit. The tonsils and adenoids were removed with some technical operative difficulty. Respiration was assisted intermittently. The blood loss was only $40 \mathrm{ml}$. ( $3.5 \%$ of total blood volume). The heart rate remained stable at 120 per minute. The muscle tone throughout appeared excessive. The

'The Montreal Children's Hospital. 
patient was returned to the recovery room, still intubated, at 12.30 P.M. Ventilation appeared adequate. He felt warm, and the rectal temperature on arrival at the postoperative area was $104.2^{\circ} \mathrm{F}$. Continuous artificial ventilation was begun and an intravenous infusion of $\mathbf{5}$ per cent glucose and water was started in the long saphenous vein.

At 12.40 P.M. the patient appeared less deeply anaesthetized, while at the same time there was increased skeletal muscle tone. Suddenly the pulse rate dropped to 40 per minute. Atropine $0.6 \mathrm{mg}$. was given intravenously, but the pulse rate dropped to 26 per minute, and two minutes later, at 1.00 P.M., there was cardiac arrest. Attempts at resuscitation by external cardiac massage, with jugular vein cannulization and electrocardiographic control commenced immediately. Five $\mathrm{ml}$. of sodium bicarbonate ( $10 \mathrm{mEq}$.), $5 \mathrm{ml}$. of calcium gluconate 10 per cent, and Isoprotorenal (1/50,000 in the drip) were given intravenously. External cardiac massage produced constricted pupils and palpable femoral pulsation. At no time did any electrical activity appear on the cardioscope. Five ml. of potassium chloride ( $10 \mathrm{mEq}$.) was given into the infusion on the theoretical advice of a research physiologist contacted by telephone. The patient was pronounced dead at 2.30 P.M.

Blood taken from the jugular vein during resuscitation was reported later to have the following electrolyte levels: sodium $112 \mathrm{mEq}$, potassium $19 \mathrm{mEq}$., chloride $81 \mathrm{mEq}$., and calcium $8.9 \mathrm{mg}$. The potassium level was checked in analysis and verified. Central venous blood was also reported to have hydrogen ion concentration of $138 \mu \mathrm{mEq} . / \mathrm{L}$., ( $\mathrm{pH} 6.8$ ), $\mathrm{P}_{\mathrm{CO}_{2}} 69 \mathrm{~mm}$. $\mathrm{Hg}$, bicarbonate 9.8 $\mathrm{mEq} . / \mathrm{L}$., indicating extreme acidaemia secondary to extreme hypobasaemia and moderate hypercapnia. The succinylcholine used with this patient was in a $20 \mathrm{ml}$. vial of 2 per cent solution which had been used previously and was used in subsequent patients with no abnormal results.

A complete post mortem examination was undertaken three hours after death, and a summary report provided by Dr. J. S. Fawcett. Height and weight were both below the third percentile. No single lesion or combination of lesser changes suggestive of a fatal clinical condition was present. There was a fresh adenotonsillectomy wound. There was flexion of the wrists and marked plantar flexion at the ankles due to muscle spasm, not to rigor mortis. There was systolic contraction of the left ventricle, and a subarachnoid haemorrhage (staining) focal and insignificant over the left superior frontal gyrus, with slight symmetrical notching (possibly artefactual) of the cerebellar tonsils and uncus. The brain weighed $1211 \mathrm{gm}$. Histologically there was mild laryngo-tracheitis (intubation); slight cervical lymphadenitis; coagulative necrosis of single myocardial fibres, especially of the left ventricle (terminal anoxia) and slight (focal) hepatocellular coagulative necrosis in the left lobe of the liver. The splenic follicles showed "toxic" granulation, and the one parathyroid gland examined microscopically was normal. Grossly and microscopically, there appeared to be no change in skeletal muscle to substantiate a diagnosis of myotonia congenita or myotonic dystrophy. Some muscle fibres appeared hypertrophied, but by measurement the largest of these was $\mathbf{8 5}$ micra in diameter. Some fibres showed hyaline swelling and occasional contraction bands were present in some skeletal muscle 
fibres. These were thought to be of no diagnostic significance. Morphological changes of systemic hyperthermia, i.e. peripheral vaso-dilatation and cardiac dilatation, were not present. Glycogen was absent in alcohol-fixed sections of the cardiac and skeletal muscles and in similarly processed liver sections, glycogen was absent from the cytoplasm but present in the nuclei. Tissue culture from autopsy specimens for viral infection showed no cytopathic changes. Cholinesterase studies on blood taken from the patient before and after death were found to be normal. Normal bacterial culture was obtained from the airway, and no growth was obtained from spleen sections. One sister with a history of grimacing was checked neurologically and was found normal, as was her electromyogram.

\section{Comment}

A similar dramatic reaction to succinylcholine was recorded last year. ${ }^{1}$ Patterson $^{2}$ produced a brief hypertonicity with succinylcholine in a patient known to have myotonia congenita. Malignant hyperthermia is more commonly reported as having a familial, ${ }^{8}$ infective, ${ }^{4}$ or idiopathic origin. ${ }^{5}$ A metabolic error or enzymatic aberration has been theoretically suggested as the aetiology of hyperthermia." Such an unidentified disturbance could have been the basis of this fatality.

\section{RÉSUMÉ}

Le 15 novembre 1965, un garçon de $5 \%$ ans était admis à l'hôpital Montréal Children pour subir une amygdalectomie. Son histoire faisait mention d'un poids inférieur à la naissance, à lâage de deux semaines et demie, d'une admission à l'hôpital pour une broncho-pneumonie. Ultérieurement il s'est développé lentement; à l'âge de cinq ans, il a été traité poux nervosité, nycturie et croissance en retard. A son admission, il pesait $\mathbf{1 5 . 5}$ kilogrammes. Les examens de laboratoire n'ont rien révélé d'anormal.

Comme sédation, il a reçu $40 \mathrm{mg}$. de pentobarbital deux heures avant l'opération et, une heure avant l'opération, morphine $1.5 \mathrm{mg}$. et hyoscine $0.15 \mathrm{mg}$. Sa température était de $98^{\circ} \mathrm{F}$., son pouls 92 et sa respiration 22 . Nous avons fait l'induction avec du protoxyde d'azote, de l'oxygène et de l'halothane avec un circuit semi-fermé. L'induction s'est faite sans incident jusqu'au moment où nous lui avons donné $15 \mathrm{mg}$. de succinylcholine pour l'intubation. Les muscles de tous ses membres sont entrés dans un état de spasme prononcé, il est devenu en apisthotonos, ses muscles abdominaux sont devenus rigides et ses masséters fortement contractés. La ventilation artificielle avec un masque est demeurée facile. Son pouls n'a pas changé et, en deça de trois minutes, sa respiration spontanée est apparue. Nous avons ajouté du méthoxyfluorane et nous avons donné une deuxième dose de succinylcholine. La rigidité des muscles squelettiques a augmenté et ce n'est qu'avec beaucoup de difficultés que nous avons réussi l'intubation endotrachéale. L'opération s'est terminée et nous avons retourné le malade à la salle de réveil, le tube en place durant $13 \frac{1}{2}$ heure après l'induction. 
La ventilation nous a paru adéquate, mais la température rectale à son arrivée était de $104.2^{\circ} \mathrm{F}$. Nous avons commencé de la ventilation artificielle continue et avons installé dans une veine un soluté glucosé 5 pour cent dans l'eau. En deça de 10 minutes, l'anesthésie nous a semblé moins profonde, mais à ce moment le tonus musculaire était augmenté. Le pouls soudainement a ralenti a 40 pour min et, en dépuit de l'administration de $0.6 \mathrm{mg}$. d'atropine par voie endoveineuse, le cœur s'est arrêté en peu de temps. Toute tentative de réanimation s'est avérée inutile.

Durant la réanimation, nous avons prélevé du sang dans la jugulaire et l'analyse a montré une acidose métabolique marqué ( $\mathrm{pH}$ 6.8) un taux inférieur de sodium et un taux élevé de potassium. Trois heures après la mort, la nécropsie n'a pas mis en évidence la moindre lésion ou association de changements pouvant faire songer à un état fatal.

\section{REFERENCES}

1. Case Report 285. A.S.A. News Letter. 29: 9 (1965).

2. Patrerson, I. S. Generalized Myotonia Following Suxamethonium: A Case Report. Brit. J. Anaesth. 34: 340 (1962).

3. Denbonough, M. A.; Forster, J. E.; Lovelx, R. R. H.; Mapleston, P. A.; \& Vinc.ers, J. D. Anaesthetic Deaths in a Family. Brit. J. Anaesth. 34: 395 (1962).

4. ModelL, J. H. Septicemia as a Cause of Immediate Post-Operative Hyperthermia. Anesthesiology. 27: 329 (1966).

5. Samman, L. J.; Harvard, E. S.; \& Eger, E. I. Hyperthermia during Anesthesia. J.A.M.A. 190: 1029 (1964).

6. WIIson, R. D.; Nichols, R. J.; Dent, T. E.; Alien, C. R. Disturbances of Oxidative Phosphorylation Mechanism as a Possible Etiological Factor in Sudden Unexplained Hyperthermia Occurring during Anaesthesia. Anesthesiology. 27: 231 (1966). 